Asya Araştırmaları Dergisi / Sayı: 1 / Cilt: 4 / ISSN: 2667-6419

\title{
RECEPTION OF CHINESE BELT AND ROAD INITIATIVE IN VIETNAM: BETWEEN SECURITY CONCERNS AND INFRASTRUCTURAL FINANCING NEEDS*
}

\author{
Vietnam'da Çin Kuşak ve Yol İnisiyatifinin Alımlanması: \\ Güvenlik Kaygıları ile Altyapı Finansmanı Gereksinimleri Arasında
}

Ulaş Başar GEZGİN**

\begin{abstract}
In this article, we elaborate on how Chinese Belt and Road Initiative projects (formerly known as One Belt One Road) are received in Vietnam. Sino-Vietnamese relations are usually shadowed by the maritime dispute over South China/East Vietnam Sea. Thus, some of the Vietnamese researchers are skeptical and cautious about BRI expansion. Although it predominantly appears to be an economic model, BRI routes pass through disputed waters which makes us think that it also has a geostrategical dimension. However, Vietnam as a country of infrastructure gap, in which energy demand grows faster than the economy, needs BRI infrastructure investments to cut the transportation and energy costs, and accordingly become more competitive. In that sense, BRI projects are definitely needed. As a response to BRI, a group of opposing countries, U.S., Australia, Japan and India developed the idea of Indo-Pacific Strategy (IPS) excluding China. Vietnam, rather than becoming a battleground of an international conflict as is the case in the 20th century, applies a balancing and hedging strategy. BRI also activates IPS which may offer attractive proposals to lure Vietnam away from China. On the other hand, Sino-Vietnamese economic relations are very deep and close. Thus, Vietnam is not willing to risk losing one for another. In this article, Vietnamese positions over BRI projects and the likely future of Vietnam through BRI are presented and discussed.
\end{abstract} relations.

Keywords: Belt and Road Initiative, One Belt One Road, Vietnam, BRI-skepticism, and Sino-Vietnamese

$\ddot{O} z$

Bu makalede Çin Kuşak ve Yol İnisiyatifi (KYİ, eski adıyla 'Bir Kuşak Bir Yol') projelerinin Vietnam'da nasıl alımlandı̆̆ üzerinde duruyoruz. Çin-Vietnam iliş̧kileri çoğunlukla Güney Çin/Doğu Vietnam Denizi’ndeki kara suları anlaşmazlı̆̆ ile gölgeleniyor. Bu nedenle, kimi Vietnaml araştırmacılar KYİ konusunda kuşkucu ve tedbirli. KYİ, ağırlıkl olarak ekonomik bir model gibi görünse de, KYİ yollarl, tartışmalı kara sularından geçiyor ki, bu, bize bunun jeo-stratejik bir boyutu olduğunu düşündürüyor. Ancak, enerji talebinin ekonomiden daha hızlı büyüdüğ̈̈ bir altyapı uçurumu ülkesi olan Vietnam, ulaşım ve enerji maliyetlerini düşürerek daha yarışmacı olabilmek için KYİ'nin altyapı yatırımlarına gereksinim duyuyor. Bu anlamda, KYI projeleri kesinlikle gerekli. KYI' ye bir yanıt olarak, bir grup karşl çıkan ülke, ABD, Avustralya, Japonya ve Hindistan, Çin’i dişlayan Hint-Pasifik Stratejisi (HPS) düşüncesini geliştirdiler. Vietnam, 20. yüzyılda olduğu türden uluslararası bir çatı̧̧ananı çarpışma alanı olmak yerine, bir dengeleme ve risk düşürme stratejisi uyguluyor. KYI bir yandan da HPS'yi harekete geçirmiş oluyor ki bu, Vietnam'l etkilemek için çekici öneriler getirebilir. Diğer yandan, Çin-Vietnam ekonomik ilişkileri çok derin ve yakın. Bu nedenle, Vietnam, biri için diğerini kaybetmeyi göze alacak değil. Bu makalede, Vietnam'in KYİ projelerine ilişkin duruşu ve Vietnam 'n KYİ dolayımındaki olası geleceği sunuluyor ve tartışmaya açıllyor.

\footnotetext{
*DOI: 10.34189/asyam.4.1.009

*** Prof. Dr., Duy Tan University, Danang, Vietnam, ulasbasar@gmail.com
} 
Anahtar Sözcükler: Kuşak ve Yol İnisiyatifi, Bir Kuşak Bir Yol, Vietnam, KYİ-kuşkuculuğu ve Çin-Vietnam
ilişkileri.

\section{Introduction}

Belt and Road Initiative in Vietnam has had a mixed reception. After this introduction, we will see various views on BRI from the Vietnamese side and discuss the likely future of Vietnam through BRI.

Among the BRI projects in Vietnam, Kunming-Hanoi Highway and Vietnam Long Jiang Industrial Park are completed, Hanoi Light Rail and Vinh Tan 1 Coal-fired Power Plant are under construction, and Kunming-Hanoi Road, and China-Laos-Vietnam Grid Connection are planned (Hong \& Johnson, 2018). Another proposed project is a rail link from Phnom Penh to Ho Chi Minh City (Miu, Chong \& Leung, 2017; World Bank, 2019). The proposed Pan-Asia Railway Network extending from Kunming, China to Bangkok, Thailand passes through Vietnam and Cambodia (Miu, Chong \& Leung, 2017). This rail line is the backbone of China-Indochina Peninsular Economic Corridor (CIPEC) (Lehman Brown, 2019). A World Bank report considers Long Jiang Industrial Park as a success story, at the same time noting that not all the BRI projects in the South East Asian region met the expectations (World Bank, 2019). Another project which is more controversial is Vietnam National High Speed Train which is expected to connect Hanoi with Ho Chi Minh City. It was planned, halted and reconsidered. Its implementation date, if ever, is not specified (World Bank, 2019). Before passing to the next topic, we need to state that it is sometimes difficult to distinguish which Chinese investments in Vietnam are a part of BRI or not. However, infrastructure projects are usually classified as BRI.

Vietnam is in the process of becoming a site of Chinese low value-added production (Chan, 2017), as the core of industries that are deemed strategically important by the Chinese government are kept in the Chinese mainland. This is opposite of what South Korea, for example, does in Vietnam, as the latter moves even the electronics production to Vietnam. BRI can be expected to bolster this type of move or reverse it through Chinese high-tech investments in Vietnam. On the other hand, since from the Chinese side, engaging with Vietnam without any serious conflict is unlikely, Vietnam is not even considered to be a major destination for BRI projects. The other reason is geographical: It is more rational to open a gateway through the Indian Ocean, rather than opening another one in the Pacific or the vicinity through Vietnam. It is not helpful to fix the problem of China's Malacca dilemma which will be explained in the next section. It can also be stated that Chinese and Vietnamese economies are already very well connected. The gains from additional trade through BRI will be relatively minimal compared to what China expects from the Eurasian connections, and before all the China Pakistan Economic Corridor. The United States is already strong in the Pacific, but the Eurasian land mass has been almost untouched. Thus, compared to expected effects of BRI in Central Asia and West Asia, BRI budget for projects in Vietnam will be smaller in scale. In fact, this in one way can be an advantage for Vietnam: China would not put a lot of pressure over Vietnam for the implementation of BRI projects in Vietnam, as they are not vital for the overall BRI planning. On the other hand, as long as Sino-American trade conflict lingers on, China will still need Vietnam as a site to circumvent country of origin restrictions against Chinese products. Vietnam is considered to be one of the winners of this trade conflict (Elmer, 2018, 2019; Holland, 2019; Pham \& Murray, 2018).

Obama's response to the rise of China was the model of Pivot to Asia and Trans Pacific Partnership (TPP) (see Gordon, 2012; Ling, 2013). However, through Trump's presidency, U.S. is more inward looking (see Mahmood \& Cheema, 2018). Nevertheless, a new American strategy was needed to counter the influence of OBOR in the region. That is how, Indo-Pacific Strategy (IPS) emerged which consisted of a loose anti-China partnership of U.S., India, Japan and Australia (see Pant \& Rej, 2018). Fortunately, Vietnam is smart enough in not taking sides in this conflict: The dragon country rather prefers to take advantage of both camps through international trade and investments. The escalation of an BRI-IPS conflict is obviously detrimental to Vietnam, as South China-East Vietnam waters area is expected to be the first confrontation field in such a case. An example of Vietnam's hedging strategy can be seen in contracting 
the metro project in Ho Chi Minh City to Japanese investors, and that in Hanoi to Chinese ones. Such a hedging and balancing strategy is also instrumental to avoid increasing dependence of Vietnamese economy over Chinese trade and investments through BRI (Shoji, 2018). During the Sino-Soviet split, Ho Chi Minh was successful in securing support from both sides through non-sectarianism (Gezgin, 2019). In the history of international left, such a stance was called as 'Ho Chi Minh attitude'. Young activists used to be advised to act like Ho Chi Minh not to be a party to such conflicts (Belli, 1994). Vietnam's hedging and balancing strategy appears to be the continuation of such a position.

\section{Vietnamese Views on BRI Projects in Vietnam}

Chan (2016) categorizes Vietnam as a 'cautiously supportive' country with regard to BRI together with Myanmar and the Philippines. The continuum ranges from the most supportive ones such as Cambodia, Laos, Pakistan, Thailand and Turkey, and not supportive ones such as India, Japan and USA. We can also add Australia to this list for the last category. Ghiasy, Su \& Saalman (2018) name Vietnam as the most BRI-skeptic in South East Asia yet notes the positive reception of BRI in Vietnam and close ties between the two countries. Sino-Vietnamese maritime conflict is a big problem for not only implementation of BRI projects in Vietnam and in South East Asian region, but also for Chinese international relations in general. This partially explains Vietnam's ambivalent, unclear standing towards BRI (Hiep, 2018).

According to Toai, Guan, \& Ghimire (2018), BRI projects will ultimately be beneficial for Vietnam. Thanks to BRI, infrastructure projects will better connect Vietnam to the world which is expected to boost Vietnamese economic development. The building of ports, railways, highways, energy lines and improvement of the existing ones will not only attract more Chinese investment to Vietnam, but nonChinese foreign investment as well (Toai, Guan, \& Ghimire, 2018). Moreover, these BRI infrastructure investments can greatly contribute to ASEAN economic integration and intra-ASEAN trade. Likewise, we can expect to see more tourists in Vietnam not only from China, but from non-Chinese Asian and nonAsian countries, as infrastructural development will lead to a booming tourism sector in Vietnam in addition to the current very high number of incoming tourists.

Sino-Vietnamese trade is expected to increase as a result of BRI projects in Southern China which will improve China's internal infrastructure and regional connectivity and the projects in Vietnam, which means more Chinese goods and services flowing to Vietnam. We will see whether this Chinese inflow to Vietnam will be coupled with Vietnamese inflow of goods and services to China. If the additional Sino-Vietnamese trade through BRI will be mostly based on sales of Chinese electronic goods and Chinese mining activities in Vietnam, this will exacerbate trade imbalance problem to the disadvantage of the Vietnamese national budget. Thus prescient, precautious and carefully calculated planning and action are needed from a Vietnamese perspective.

Through a SWOT analysis of Vietnam with regard to BRI, Toai, Guan, \& Ghimire (2018) mention Vietnam's geo-strategical importance in the region, natural resources, young work force, lower labor costs as the strengths; "weak military power, lack of construction funds, slow industrial development, [and] trade imbalance" as the weaknesses; "infrastructure building, foreign investments, economic developments, [and] urbanization" as the opportunities, and finally, "geopolitical security risks, [and] environmental issues" as threats (p.178). However, this analysis is clearly misleading and confusing and does not properly follow SWOT methodology. BRI from a Vietnamese perspective and Vietnam from a BRI or Chinese perspective are mixed in a single SWOT analysis. The listed strengths make sense from a BRI perspective of Vietnam, but "weak military power" as a weakness can't be from a BRI point of view. Furthermore, it is not clear how such a point is related to BRI which is mostly a non-military, economic project. Same holds for trade imbalance. It is a problem only from a Vietnamese perspective. Thus, this discussion requires not a single mixed SWOT, but two separate SWOT analyses. Additionally, urbanization is listed as an opportunity, but a higher urbanization rate can bring problems to Vietnam as well. It is a double-edged sword. 
According to Toai, Guan, \& Ghimire (2018), Vietnam has untapped natural resources especially minerals. Mining companies are very active in China and Laos, but not in Vietnam. In the SWOT analysis, this is listed as a strength, but in fact it can better be considered as an opportunity. Secondly, the mining activities need to be conducted very carefully, in an environment- and people-friendly way. Otherwise, it has the potential to feed anti-China sentiment in Vietnam.

In this context, Toai, Guan, \& Ghimire (2018) rightly warn that if infrastructure projects would not be planned carefully taking into account all the risks, they may cause "permanent environmental damage" as well as "pollution, the spread of invasive species, restrictions on animal movements, habitat loss, and wildlife mortality" etc. (p.180). Another concern is whether BRI projects would bring second-rate Chinese companies with less credible reputation to Vietnam (Damuri et al., 2019). Transparency and higher quality are needed.

Hiep (2018) proposes that Vietnam is cautious about BRI due to "its distrust of Beijing and concerns about the strategic implications of the initiative in the context of the South China Sea disputes; the unattractive commercial terms and conditions of Chinese loans; and Vietnam's access to other options" (p.1). The first point is clear. The second point involves high interest rates on Chinese loans and requirement of uses of Chinese technologies and preference for Chinese contractors. Furthermore, the priority projects of both parties don't necessarily match. According to Hiep (2018), the fact that the negotiation of the memorandum of understanding on BRI between Vietnam and China had taken 2 years, which is much longer than those with some other countries is a clear sign to show that they have disagreements. Furthermore, Hiep (2018) notes the complaints about Chinese investments in Vietnam both prior to and in parallel with BRI in Vietnam. Regarding the third point, Japanese investment which is perceived to be looser on terms and conditions and Vietnamese private investments are considered to be strong alternatives to BRI projects in Vietnam (Hiep, 2018). Vietnamese public is more positive about Japanese investments compared to Chinese ones, as the maritime dispute and historical animosities weigh heavier. Considering these points, Hiep (2018) concludes that BRI projects will be slow in Vietnam, as Vietnam has reservations over some of the expected consequences of BRI, and is in the process of evaluating alternatives such as Japan to counter increasing Chinese influence over Vietnam.

In fact, a tacit acceptance by Chinese government that the Sino-Vietnamese maritime conflict can't be solved in the near future can be inferred from the fact that China is looking for a shortcut to the Southwest Asian oil regions through Pakistan. China's so-called 'Malacca Dilemma' is based on the fear that in a worst-case scenario of a Sino-American military confrontation in South China/East Vietnam Sea, China's energy supply lines and maritime trade routes would be effectively blocked. Thus, China is in favor of an alternative shortcut which is materialized in China Pakistan Economic Corridor (CPEC) project, a milestone in BRI (Gezgin, in press).

It is obvious that the maritime dispute leads to negative perceptions of China with effects over reception and interpretation of $\mathrm{BRI}$ projects in Vietnam $(\mathrm{Pu}, 2016)$. On the other hand, Vietnam became one of the founders of Asian Infrastructure Investment Bank. Pu (2016) proposes that with favorable conditions, Vietnam will be eager to approve BRI projects in Vietnam, regardless of the maritime dispute. On the other hand, there are other problems associated with Chinese investments in Vietnam such as projects exceeding the initial cost estimations, sluggishness and instability of the Chinese currency (Nguyen et al., 2018). Nevertheless, another factor for positive reception of Chinese investments in Vietnam is Vietnamese government's willingness to diversify the funding sources, adding some others to already existing relations with the World Bank and the Asian Development Bank (Nguyen et al., 2018).

Le, Tran \& Duc (2019) observe that Vietnamese respondents in their study expect benefits from BRI for Vietnam in a way similar to what is proposed in the relevant research, while they also mention increased competitive pressure, trade deficit to the disadvantage of Vietnam, increase in state debt, environmental problems and likely escalation of Sino-Vietnamese maritime conflict as the expected negative consequences of BRI. Converging with these concerns, in a conference on Belt and Road Initiative that 
was organized in Hanoi, the downsides of BRI projects in Vietnam were listed as "insufficient protection of labour rights, notorious environmental record of Chinese firms, lack of transparency, and China's challenging of internationally recognised dispute settlement mechanisms" (Viet Nam News, 2017a). Alongside BRI, Vietnam prefers a bilateral project which is called as Two Corridors, One Economic Belt which is "is expected to develop a road and express railway system between Việt Nam and China, including the Nanning-Lạng Sơn-Hà Nội-Hải Phòng-Quảng Ninh, Yunnan-Lào Cai-Hà Nội and the belt road in the Gulf of Tonkin” (Viet Nam News, 2017b).

\section{The Future of Vietnam through BRI}

Chinese investments in Vietnam are mostly in manufacturing, with smaller proportions of infrastructure (water, power, gas) and real estate investments. These investments are almost in all provinces of Vietnam, but especially concentrated in Binh Thuan, Tay Ninh and Bac Giang (PwC, 2019). The first two are located in South Vietnam, and the last one is in North Vietnam close to Vietnam-China border. With the increasing connectivity through BRI projects, it may be expected that especially Vietnamese provinces bordering China would attract more investment.

A PwC report identifies "cost-competitive labor force", "strong need to improve and develop infrastructure", and "emergence of an upper middle class" as the key characteristics of Vietnam with regard to BRI (p.11). BRI projects in Vietnam are expected to benefit first of all, garment and consumer electronic manufacturing, secondly, energy and transport infrastructure, and thirdly automotive manufacturing (PwC, 2019). According to the estimations, manufacturing labor costs are increasing in a lower rate in Vietnam compared to the situation in China and Thailand. For the second point, according to the Vietnamese official planning, only 1/6th of the roadways are already in use. Much more will be needed. This deficiency matches as hand and glove with BRI plans. Similar forecasts are made for power generation and use. Better connectivity will bring the need for a higher number of cars which, together with the increasing income levels in Vietnam, will lead the way for a much higher number of car sales. In that sense, BRI may potentially change the typical Vietnamese traffic 'landscape' where a high proportion of vehicles on the roads are motorbikes, rather than cars. Vietnam has the highest number of motorbikes per capita in the world after Thailand (closely following Thailand) (Poushter, 2015). With economic development, as was the case in China, the bicycle users can switch to motorbikes, and motorbike drivers to cars. Currently, car penetration rate in Vietnam is much lower than that in China (PwC, 2019). In the region, South Korea, Japan and Malaysia top the list $(\mathrm{PwC}, 2019)$. This expected transition is also supported by the manufacturing of the first Vietnamese national car, Vinfast, which is more affordable for Vietnamese customers compared to imported cars (Hiep, 2019). We can also add to PwC predictions that BRI can also benefit all sorts of electronics including air conditioning and fans, if the improvements in transport would make the electronic products cheaper and if the electricity would be cheaper with increasing energy production and better supply networks.

According to PwC (2019), as to the market share of road and bridge construction in Vietnam, only less than half is undertaken by international companies. Japan and South Korea each hold $10 \%$. The figures for U.S. and China are 6\% and 3\% respectively. India has another 2\% and Australia 1\% (PwC, 2019). The combined market share for the countries of Indo-Pacific Strategy (IPS) is 19\% which is higher than China's share. With BRI projects in Vietnam, the market share is expected to change to the advantage of China. It is also likely that Vietnamese market share will drop if international projects with favorable terms would be offered. Since IPS countries will be increasingly in direct competition with China in arenas such as Vietnam, they may also come up with projects with looser terms and conditions. It will be up to Vietnamese government to bargain the best out of this BRI-IPS competition.

Vietnam's demand for electricity increased much more than GDP growth which points to infrastructure gap in terms of energy (PwC, 2019). BRI can fill this gap and this will be positive for Vietnamese development, as energy supply not matching economic development will ultimately decelerate growth. For example, when Vietnam would have power cuts due to mismatch of electricity demand and 
supply, this will not only slow down production, but also hurt investor confidence. One of the reasons for why international investors prefer Vietnam is relatively good infrastructure compared to some other countries in the region ( $\mathrm{PwC}, 2019)$. Thus, this point can't be underestimated. We see that Vietnam's ratio of infrastructure spending over GDP is above 5\% which is better than the case in some other South East Asian countries and has an increasing trend (HSBC, 2018), but this alone will not be sufficient to meet the targets, and this high proportion may be viewed as an indicator of rather than a solution to the burning need for infrastructural investments in Vietnam. In most of the country, electricity and telecom cables are yet to be moved to underground, which can even be taken as a sign of the level of economic development. Vietnamese government plans to 'bury' all these cables that look like an inextricable spaghetti (or 'spider webs' in local Vietnamese vocabulary) above Vietnamese streets by 2025 (Viet Nam News, 2019). BRI may be helpful for this target of 'cable burial'.

We can list a set of other expectations both positive and negative: A Moody's report expect that Vietnam and Thailand will see the highest increase in debt to GDP in South East Asia as a consequence of BRI projects (Moody's Analytics, 2019). More Chinese and non-Chinese foreign visitors to Vietnam including tourists and businesspeople are expected in Vietnam as a consequence of BRI (Loc, 2018). With environmental degradation and trans-border water security problems, BRI may also bring water shortage problem to Vietnam (cf. Hoering, 2018). As to the cultural ties, BRI is thought to expand the influence of Chinese language in Vietnam through offerings of a higher number of Chinese language courses and other subjects such as economics and trade in Chinese language (Le, 2019). Finally, Chinese currency is becoming more common due to the existing Chinese investments and expected BRI projects in Vietnam (Brugier, 2014).

Guo and Luo (2018) have an interesting view: They claim that due to the increasing connectivity through BRI projects, China's agricultural trade increases with the neighboring countries including Vietnam. As a result, while overall Chinese budget deficit brings surplus, the opposite takes place for Chinese agricultural budget in trade with Vietnam. In other words, BRI widens China's agricultural trade deficit (Guo \& Luo, 2018). Thus we can infer that an advantage of BRI for Vietnam will be better access to neighboring markets to sell Vietnamese agricultural products. With China's move from agriculture to information economy, economically less developed neighboring countries will increasingly become a part of China's unnamed division of labor. On the other hand, this may potentially slow down Vietnam's transition from an agricultural to an industrial and informational economy, since Vietnamese agricultural activity will be economically more rewarding.

As a response to or as a development accompanying BRI, in the near future, with the opening of Kra Canal (also known as 'Thai Canal') connecting Pacific and Indian Oceans by bypassing the sea route through the Straits, Indo-Vietnamese relations and especially trade can be developed which can support Vietnam's hedging and balancing strategy. In such a case, Vietnam's southern tip will gain even more prominence, and ports to meet the sea trade demands are expected to be built (Chan, 2016).

For environmental problems, not only for Vietnam, but for all BRI countries, we need green initiatives for decarbonization and take actions against expected negative environmental impacts (Jun \& Zadek, 2019). Rather than with a carbon-based model, maybe with the right directions, BRI can be an opportunity for Vietnam to move closer to alternative energy initiatives. The first that comes to mind is the solar energy. Tropical Vietnam's solar potential is clearly underutilized. Recently, Vietnam opened the largest solar farm in South East Asia in partnership with a Thai company (Quy, 2019). China is the world leader in solar panel production (Beinhart, 2018). Thus, the winds of BRI may also bring more Chinese solar power companies which can tap Vietnam's underutilized solar energy potential. It is among Vietnamese government's plans to increase the share of solar power in energy production to $20 \%$ by 2050 from the current $0.01 \%$ (Quy, 2019). 


\section{Conclusion}

In this article, we focused on how BRI projects are received and interpreted in Vietnam. Of course, it is hard to predict the future. But nevertheless we can have certain expectations that would be more probable than others: We expect that Vietnam will continue with the hedging and balancing strategy. BRI projects in Vietnam that seem to be less risky and more favorable will proceed. On the other hand, China will not have a priority over other countries in terms of investments. Vietnamese government knows very well that economic dependence on China needs to be countered by diversifying trade and investment relations. If China Pakistan Economic Corridor Project would be a success, Vietnam's significance in the overall BRI model will be even less visible, which will put less Chinese pressure over projects in Vietnam. In this way, Vietnamese government will be able to buy time to develop relations with other countries especially India which is willing to invest in Vietnam and which will be closer to Vietnam if Thai Canal would be operational. Nevertheless, Vietnam will be indispensable for China, but not necessarily for connectivity. It will be for the opportunity for not getting harmed by the Sino-American trade war through Chinese products with 'made in Vietnam' labels. All these expectations are based on the assumption that there won't be any large scale Sino-American or Sino-Vietnamese military confrontation at disputed waters. This assumption can blow all these discussions here as a house of cards. China will definitely be more assertive in foreign policy simultaneously with BRI projects. This can have a destabilizing effect over Chinese economic projects, as a higher number of countries would turn to be more skeptical of China in such a situation.

\section{References}

BEINHART, L. (23 August 2018). Why China, and not the US, is the leader in solar power. Al Jazeera. https://www.aljazeera.com/indepth/opinion/china-leader-solar-power-180822102606141.html

BELLI, S. (1994). Boşuna mı çiğnedik? [What is all in vain?] İstanbul: Belge.

BRUGIER, C. (2014). China's way: the new Silk Road. European Union Institute for Security Studies, 14. https://www.files.ethz.ch/isn/182346/Brief_14_New_Silk_Road.pdf

CHAN, G. (2018). China's High-speed Rail Diplomacy: Global Impacts and East Asian Responses. Seoul, Republic of Korea: The East Asia Institute.

http://www.eai.or.kr/main/english/search_view.asp?intSeq=9447\&board=eng_report

CHAN, S. (2018). The belt and road initiative: Implications for China and East Asian economies. The Copenhagen Journal of Asian Studies, 35(2), 52-78.

DAMURI, Y.R., Perkasa, V., Atje, R. \& Hirawan, F. (2019). Perceptions and readiness of Indonesia towards the Belt and Road Initiative: Understanding local perspectives, capacity, and governance. Center for Strategic and International Studies. Jakarta: Indonesia.

https://www.csis.or.id/uploads/attachments/post/2019/05/23/CSIS_BRI_Indonesia_r.pdf

ELMER, K. (8 May 2019). US-China trade war is a gift that keeps on giving for Vietnam. South China Morning Post.

https://www.scmp.com/news/china/diplomacy/article/3009405/us-china-trade-war-gift-keeps-givingvietnam

ELMER, K. (12 December 2018). Vietnam uses US-China trade war to rebalance its economic and security relationships. South China Morning Post.

https://www.scmp.com/news/china/diplomacy/article/2177405/vietnam-uses-us-china-trade-warrebalance-its-economic-and

GEZGIN (in press). Belt and Road Initiative: Globalization with Chinese Characteristics or the Revival of Historical Silk Road? 
GEZGIN, U.B. (2019). Çin-Vietnam İlişkileri: Sömürgelikten Yoldaşlığa, Oradan Nereye? [SinoVietnamese Relations: From Colonized to Comradeship and from There to Where?] M5 Magazine, 334, 50-59.

http://m5dergi.com/2019/05/cin-vietnam-iliskileri-somurgelikten-yoldasliga-oradan-nereye/

GHIASY, R., Su, F. \& Saalman, L. (2018). The 21st Century Maritime Silk Road: Security implications and ways forward for the European Union. Stockholm: Stockholm International Peace Research Institute.

https://www.sipri.org/publications/2018/other-publications/chinas-belt-and-road-initiative-securityimplications-and-ways-forward-european-union

GORDON, B. K. (2012). Trading Up in Asia: Why the United States Needs the Trans-Pacific Partnership. Foreign Affairs, 17-22.

GUO, Z., \& Luo, H. (2018, July). Analysis of Competitiveness and Complementarity of China-Vietnam Agricultural Product Trade under the Background of" the Belt and Road". In 3rd International Conference on Contemporary Education, Social Sciences and Humanities (ICCESSH 2018) (pp.974-982). Atlantis Press.

https://download.atlantis-press.com/article/25898118.pdf

HIEP, L. H. (2019). Vietnam's industrialization ambitions: the case of Vingroup and the automotive industry. ISEAS Yusof Ishak Institute, 2, 1-19.

https://think-asia.org/bitstream/handle/11540/9511/TRS2_19.pdf?sequence=1

HIEP, L. H. (2018). The Belt and Road Initiative in Vietnam: Challenges and Prospects, Perspective. ISEAS Yusof Ishak Institute, 18, 1-7.

https://think-asia.org/bitstream/handle/11540/8138/ISEAS_Perspective_2018_1850.pdf?sequence=1

HOERING, U. (2018). China's Long March 2.0: The Belt and Road Initiative as development model. Hamburg: Verlag Hamburg.

https://www.asienhaus.de/archiv/asienhaus/publikationen/Hoering Chinas Long-March 2.0.pdf

HOLLAND, T. (2019, 9 July). One country is winning the trade war. It's not the US and it's not China. South China Morning Post.

https://www.scmp.com/week-asia/opinion/article/3017498/one-country-winning-trade-war-its-not-us-andits-not-china

HONG, C.-S. \& JOHNSON, O. (2018). Mapping potential climate and development impacts of China's Belt and Road Initiative: a participatory approach. Stockholm Environment Institute.

https://www.sei.org/wp-content/uploads/2018/10/china-belt-and-road-initiative-hong-johnson.pdf

HSBC (2018). China's Belt and Road Initiative: The unstoppable rise of Asian infrastructure.

https://www.hsbc.com.cn/1/PA ES Content Mgmt/content/china/personal/investments/pdf/belt-androad-initiative_en.pdf

JUN, M. \& ZADEK, S. (2019). Decarbonizing the Belt and Road: A Green Finance Roadmap. Beijing: Tsinghua University Center for Finance and Development.

http://www.vivideconomics.com/publications/decarbonizing-the-belt-and-road-initiative-a-green-financeroadmap

LE, H. T. (2019, April). Research on Chinese Education in Universities in Hanoi, Vietnam in the Background of "Belt and Road". In RSU International Research Conference 2019. Proceedings of RSU Research Conference (pp.1627-1633). Bangkok, Thailand: Rangsit University. 
https://rsucon.rsu.ac.th/files/proceedings/inter2019/IN19-012.pdf

LE, Q. A., Tran, V. A., Duc, N., \& Long, B. (2019). The Belt and Road Initiative and Its Perceived Impacts on the Textile and Garment Industry of Vietnam. Journal of Open Innovation: Technology, Market, and Complexity, 5(3), 59. doi:10.3390/joitmc5030059

LEHMAN Brown (2019). The Belt and Road Initiative. www.lehmanbrown.com

LING, W. (2013). Rebalancing or de-balancing: US Pivot and East Asian order. American Foreign Policy Interests, 35(3), 148-154.

LOC, N.T.P. (2018). The "One Belt One Road" Initiative and the immigration risks from the border: The case study of China-Laos, China-Vietnam borders. Society \& Change, 12(4), 35-52.

MAHMOOD, N., \& CHEEMA, P. I. (2018). Trump and the US Foreign Policy Crisis. Strategic Studies, 38(4), 1-18.

MIU, R., Chong, T.-S. \& LEUNG, C. (2017). One Belt, One Road Moving Faster Than Expected. DBS Asia Insights.

https://www.dbs.com/in/corporate/aics/templatedata/article/generic/data/en/GR/092017/170927 insights one_belt_one_road_moving_faster_than_expected.xml

MOODY'S ANALYTICS (2019). The Belt and Road Initiative - Six years on.

https://www.moodysanalytics.com/-/media/article/2019/belt-and-road-initiative.pdf

PANT, H. V., \& REJ, A. (2018). Is India ready for the Indo-pacific?. The Washington Quarterly, 41(2), 4761.

PHAM, B. \& MURRAY, B. (18 November 2018). Here's who wins and also loses in US-China trade war: Vietnam. South China Morning Post.

https://www.scmp.com/week-asia/geopolitics/article/2173665/heres-who-wins-and-who-loses-us-china$\underline{\text { trade-war-vietnam }}$

PU, X. (2016). One Belt, One Road: visions and challenges of China's geoeconomic strategy. Mainland China Studies, 59(3), 111-132.

POUSHTER, J. (2015). Car, bike or motorcycle? Depends on where you live. PEW Research Center. https://www.pewresearch.org/fact-tank/2015/04/16/car-bike-or-motorcycle-depends-on-where-you-live/

PWC (2019). Belt and Road Country - Vietnam.

https://www.pwccn.com/en/research-and-insights/belt-and-road/publications/belt-and-road-countryvietnam.pdf

QUY, N. (9 September 2019). Southeast Asia's largest solar farm begins operations in southern Vietnam. Vn Express International.

https://e.vnexpress.net/news/news/southeast-asia-s-largest-solar-farm-begins-operations-in-southernvietnam-3979068.html

SHOJI, T. (2018). "Belt and Road" vs. "Free and Open Indo-Pacific": Competition Over Regional Order and ASEAN. The National Institute for Defense Studies, Commentary No. 88.

http://www.nids.mod.go.jp/english/publication/commentary/pdf/commentary088e.pdf

TOAI, D. B., Guan, X., \& GHIMIRE, A. (2018, November). Situational Analysis of Vietnam for Belt and Road Initiative. In 2018 International Conference on Economics, Business, Management and Corporate Social Responsibility (EBMCSR 2018) (pp.176-181). Atlantis Press. 
https://download.atlantis-press.com/article/25905223.pdf

VIET NAM NEWS (2019, 22 July). HCM City's overhead electrical cables to be buried underground by 2025. Viet Nam News.

http://vietnamnews.vn/society/522947/hcm-citys-overhead-electrical-cables-to-be-buried-undergroundby-2025.html

VIET NAM NEWS (2017a, 7 October). Tread carefully on China's Belt and Road initiative: experts. Viet Nam News.

http://vietnamnews.vn/politics-laws/395203/tread-carefully-on-chinas-belt-and-road-initiativeexperts.html

VIET NAM NEWS (2017b, 19 June). Việt Nam, China discuss defence co-operation. Viet Nam News. https://vietnamnews.vn/politics-laws/378537/viet-nam-china-discuss-defence-co-operation.html

VUONG, Q. H., VUONG, T. T., \& Ho, M. T. (2019). The 'Same Bed, Different Dreams' of Vietnam and China: How (Mis) trust Could Make or Break It. European Journal of East Asian Studies, 18(1), 93-128.

WORLD BANK (2019). Belt and Road Economics: Opportunities and Risks of Transport Corridors.

https://openknowledge.worldbank.org/bitstream/handle/10986/31878/9781464813924.pdf 